\title{
Selected Aspects of Human Resource Management in Uniformed Services
}

\author{
Tomasz Krzewiński \\ Maria Curie-Sktodoreska University, Poland \\ krzewinski@poczta.umcs.lublin.pl \\ https://orcid.org/0000-0002-4324-0480
}

Selected

Aspects

of Human

Resource

Management

in Uniformed

Services

\begin{abstract}
The aim of the article is to identify the process of human resource management and factors that influence officers' motivation in selected uniformed services. This analysis concerns the Police, Border Guard and Customs Service. This choice was made due to the diversity of the tasks carried out by the officers of these services. The concept of uniformed services, characteristics of the analysed services and the requirements for officers, the process of employees recruitment and activities aimed at maintaining officers through appropriate motivation and promotion as a form of professional development were presented. Promotion to successive levels of work is not only an important element in shaping the HR policy but also a determinant of the position of a given officer in the organization. The layout of this work presents elements of multi-aspect status of an officer in each of the studied formations in the context of the characteristics of individual services.

Purpose - Identification of the human resource management and factors that influence the motivation of officers in selected Polish uniformed services - the Police, Border Guard and Customs Service.

Design/Methodology/Approach - Review of literature, reports on empirical research and applicable legal regulations.

Findings - The basic mutual element of the Police, the Border Guard and the Customs Service is the use of uniforms and officers subordination system, but also the centralism of the organizational structure and hierarchical subordination. The activities of these services, including the implementation of the human resource management process, are regulated by relevant legal regulations. Service requirements, the scope of tasks, obligations and responsibilities, the process of employee selection, evaluation, promotion, but also retirement provisions are strictly determined. Similarities and differences in this area have been presented. The analysis of the results of empirical research allows to identify motivating and demotivating factors for officers.

Originality/Value - A comparison of selected areas of human resources management in the Police, the Border Guard and the Customs Service was made. The similarities and differences appearing in this respect were pointed out. Recommendations regarding motivating officers were presented.
\end{abstract}

Keywords - uniformed services, officer, Police, Border Guard, Customs Service, human resource management, motivators, selection of employees

\section{Introduction}

People are the most important asset of any organization, regardless of its nature. Management of uniformed services is strictly regulated by the relevant legal acts. The Police, Border Guard and Customs Service are uniformed units serving the public and intended to: protect human security and to maintain public safety and order (Act on

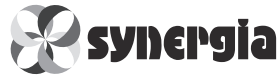

International Journal of Synergy and Research Vol. 7, 2018 pp. 97-109 
IJSR 7

the Police, 1990); protect the state border, provide border traffic control, prevent and counteract illegal migration (Act on the Border Guard, 1990); as well as perform tasks related to the implementation of income from taxes, customs duties, fees and non-tax budgetary claims, protect the Treasury's interests and protect the customs territory of the European Union (Act on the National Revenue Administration, 2016). The choice of these formations was determined by the diversity of tasks carried out by the officers of these services. The legal provisions strictly formulate the requirements, the scope of tasks, powers and responsibilities, the process of personnel selection, evaluation and promotion. It is advisable, however, to individualize the approach to human resource management in situations where it is allowed by applicable laws.

\section{Human resource management in public institutions}

The public sector is not clearly defined. In general, it can be said to provide services and, in certain cases, goods whose scope and type are not determined by the needs of buyers, but by decisions of public organizations (Zawicki, 2011). The most important conditions constituting the public sector include: state functions, expenses incurred for the performance of these functions, ownership and use of property and funds (Zawicki, 2011). The public sector includes the entire decision-making processes in the state, their results, consumption, investments and transfers as well as production carried out by public authorities, public property as well as employment in the public sector (Lane, 2000).

The approach to managing public organizations - the so-called New Public Management - is characterized by a managerial way of directing. Its main assumption is to entrust clearly defined objectives to managers, to control their achievement and to enable managers to choose their own way of implementing them. Managers of public organizations have a lot of freedom regarding the use of managerial patterns of direct management of their subordinate staff (Zawicki, 2011). The features of New Public Management include political control, relations with citizens, processes, organizational and professional development of employees as well as a flexible and thin organizational structure (Gawroński, 2014).

The most important difference between the functioning of a public organization and a private one results from the rule of law. Public organizations exist to exercise the law and every element of their existence is a product of the legislative authority (Frączkiewicz-Wronka, 2009), however, the analysis of literature allows one to conclude that the processes of managing a public organization do not differ much from the way of managing private organizations. When analysing the management of the public sector one should take into account the specificity of such an organization, which results from the characteristics of the environment, roles, structures and organizational processes specific to public institutions (Frączkiewicz-Wronka, 2009).

As the results of research carried out in many countries show, the implementation of the New Public Management concept faces a number of difficulties (Pollitt and Dan, 2011), which is worrying, as it has been noticed that the source of the organization's efficiency and competitive advantage are more and more often intangible assets, whose employees are of key importance (Pike et al., 2005). A strategic and coherent approach to managing people who individually and collectively contribute to achieving the goals 
of this organization is referred to as human resource management (Armstrong, 2007). It involves the selection of appropriate employees, their training, constant motivation and constant efforts to keep the employees in the organization (De Cenzo and Robbins, 2002). Attempts are made to identify factors affecting the satisfaction of employees in the public sector - the impact of work control, the decision-making process, support of colleagues and supervisors on the satisfaction and involvement of subordinates (Noblet and Rodwell, 2009). It is possible to observe intensification of research devoted to the relationship between motivation for public service and satisfaction (Homeberg et al., 2015), as well as other factors shaping satisfaction in public organizations (Sayce, 2016).

The key problem, however, is the implementation of the organization's goals set by its management, while satisfying the needs of employees. This makes it possible to speak about human resource management in the following contexts (Adamiec and Kożusznik, 2000):

- Legal regulations, i.e. legal acts and regulations, which define the organization's status, rights and responsibilities of employees and employers,

- Psychology, which includes knowledge of human behaviour, its motives, knowledge of personal resources, understanding of differences between individuals, individual development, learning, etc.,

- Culture, understood as patterns of human behaviours, customs, systems of values or beliefs of employees that shape employees' data and allow them to understand their behaviour,

- Ethics, which requires the managers to be familiar with ethical behaviour - honesty, integrity, justice, as well as following professional ethics, which takes sensitivity to the problems of employees and social problems into account in their actions.

\section{Uniformed services}

The term "uniformed services" is not explicitly defined in the literature on the subject. The word "service" is defined as "working for a community, done with dedication, acting for a cause or institution of public interest or an army dealing in a specific field; also: employees of this institution" (Dubisz, 2008b). In turn, the word "uniform" means "the dress code of members of some social organization, military formation or professional group" (Dubisz, 2008a). The "uniformed service", in colloquial language, is thus understood as a specialized group of persons performing special tasks, most often performed for the state, during which they wear characteristic and distinctive outfits (Szustakiewicz, 2015). No legal act defines what the term "uniformed service" means. An additional difficulty is often caused by the fact that the authors use the term "uniformed services" without specifying its definitions, treating them as widely known, listing only the formations included therein. Some authors approach this term very broadly, including all state-owned formations which perform their tasks in a uniformed manner or - like special forces - derive from uniformed formations - alongside with the Police, Border Guard, Customs Service, as well as, for example, municipal guards, persons and property security services, the Railway Protection Guard or the Forest Guard, (Maciejko et al., 2011). A narrower catalog of such services is proposed by, for example, Sławik (2011) or Kuczyński (2011). Pieprzny, however, points to the existence of armed formations in the public administration system - armed and specialized in the
Selected

Aspects

of Human

Resource

Management

in Uniformed

Services 
IJSR 7 scope of ensuring general public security and public order (e.g. Police, Border Guard) and administrative police - entities performing public safety and public order security tasks of strictly specialized character (e.g. Customs Service) (Pieprzny, 2008). It should be pointed out that the following services are always in the catalog of uniformed services: Police, special forces, Prison Guard, Customs Service, Border Guard, Government Protection Bureau, and the army. Liwo states that uniformed services are "public bodies indicated by the legislator with a special organization - in the military model - subject to the supreme government administration bodies carrying out statutory tasks within the public service related to ensuring a certain type of security and order, based on powers and legal forms of operation of competent administrations" (Liwo, 2015).

Therefore, uniformed services are attributed with features of total institutions, which affect almost all areas of their employees' lives to a large extent, shape attitudes and behaviours, e.g. by imposed regulations and rules of institutional life (JabłońskaWołoszyn and Piotrowska-Trybull, 2018). In sociology, the term "disposable groups" is used as units that perform specialized functions within a separate system of state security, also fulfilling functions useful to its citizens (Maciejewski, 2014, p. 50). These are closed groups with limited access, whose recruitment rules are conditioned by the opinion of professionals. Every aspect of the work (service) must meet a lot of rigors. The officers of the uniformed services are obliged to be ready to take immediate action in any place and at any time. They are to react quickly in the event of various threats to the state and population (Maciejewski, 2014; Morawski, 2005).

In this article, the Police, the Border Guard, and the Customs Service will be analyzed. The activities of all these services are regulated by relevant laws (Act on the Police 1990; Act on the Border Guard 1990; Act on the National Revenue Administration 2016).

\section{Tasks of the Police, Border Guard, and Customs Service}

The basic legal act regulating issues related to the Police operation is the Act on the Police (1990). According to the document, the Police is a uniformed and armed formation serving the society, intended to protect human security and to maintain public safety and order. An exemplary catalog of basic tasks of the Police includes protection of people's lives and health as well as property against unlawful attacks violating these goods, protection of public safety and order, including inviolability of public places and public transport, in road traffic and in designated waters for general use, detection of crimes and offenses, prosecution of perpetrators, control of compliance with ordinal and administrative provisions related to public activities or being in force in public places.

The Border Guard, whose activity is regulated by the Act on the Border Guard (1990), is a uniformed and armed formation intended for the protection of the state border, border traffic control and prevention as well as counteracting illegal migration. The example catalogue of Border Guard tasks includes identifying, preventing and detecting crimes and offenses, prosecuting perpetrators within their jurisdiction, ensuring security in international communication and public order within the territorial range of the border crossing as well as in the border zone, carrying out security controls, embedding and 
maintaining boundary signs on land as well as preparing, updating and storing boundary surveying and cartographic documentation, supervising the operation of Polish sea areas and compliance with regulations in force in these areas by ships, protecting the state border in the airspace of the Republic of Poland by observing aircraft and flying objects, crossing the state border at low altitudes or carrying out checks on the legality of work by foreigners, conducting business activities by foreigners or foreigners employment.

The Customs Service is a separate, uniformed formation within the National Revenue Administration (KAS), which is constituted by its officers. A comprehensive legal act regulating issues related to the operation of KAS is the Act on the National Revenue Administration (2016). KAS is a specialized government administration performing tasks related to the collection of revenues from taxes, customs duties, fees and nontax budgetary claims, protection of the interests of the Treasury and protection of the European Union customs area, as well as providing taxpayer service and support in the proper performance of tax obligations and service and support of the entrepreneur in the proper performance of customs duties. The exemplary catalogue of KAS tasks, also performed by customs officers of the Customs Service, includes: the implementation of tax revenues, fees and non-tax budgetary receivables, customs duties and other fees related to the import and export of goods, implementation of customs policy resulting from membership in the customs union within the European Union, placing goods under customs procedures and regulating the situation of goods related to the import and export of goods; examining the compliance by residents and non-residents with the limitations and obligations set out in foreign exchange regulations, identifying, detecting and preventing tax offenses related to the violation of provisions on goods that are subject to prohibitions or restrictions, preventing and investigating offenders, monitoring road traffic and rail transport of goods, performance of tasks resulting from the provisions of European Union law regulating the statistics on trade in goods between EU Member States (INTRASTAT) and trade in EU Member States with other countries (EXTRASTAT), performance of tasks resulting from prohibitions and restrictions on trade in goods with foreign countries, cooperation in the implementation of the Common Agricultural Policy or the performance of customs and tax control. It can be concluded that the functions performed by the Customs Service in Poland cover three areas protection, control and fiscal (Laszuk, 2013).

All these services, within their competences defined by the scope of tasks, are entitled to carry out operational and reconnaissance activities. Operation control carried out in an implicit manner may consist in: obtaining and recording the content of conversations conducted using technical means, including via telecommunications networks; obtaining and recording the image or sound of people from rooms, means of transport or places other than public places; obtaining and recording the content of correspondence, including correspondence carried out by means of electronic communication; obtaining and recording data contained in IT data carriers, telecommunications terminal devices, IT and tele-information systems; access and control of the contents of postal parcels. Operative and reconnaissance activities may also consist of making an acquisition, sale or seizure of objects originated from crime, forfeit or whose production, possession, carriage or trade is prohibited, as well as acceptance or presentation of financial gain, as well as of submitting a proposal to perform such activities. In the performance of
Selected

Aspects

of Human

Resource

Management in Uniformed Services 
IJSR 7

their tasks, Police officers, Border Guard officers or the Customs Service may also use the assistance of non-officers, who may be granted remuneration for their assistance. The Police, Border Guard or the National Revenue Administration also perform tasks resulting from the provisions of European Union law and international agreements as well as arrangements on the terms and in the scope specified therein. The costs of the functioning of the Police, Border Guard or the National Revenue Administration are covered by the state budget.

\section{Requirements from uniformed service officers}

Proper selection of candidates for service, from the point of view of both the image of the State whose tasks they carry out, but also from the point of view of proper performance of duties incumbent on the Police, Border Guard and Customs Service is of great importance and takes place on the basis of applicable law. The officer can be any person who has Polish citizenship, is of good repute, has no conviction (punishment) with a valid court judgment for a crime or tax-related crime, enjoys full public rights, has at least secondary or secondary vocational education as well as physical and mental ability to serve in armed formations subordinate to a particular discipline, which he/she is ready to obey, and also guarantees confidentiality in accordance with the requirements set out in the regulations on the protection of classified information. The Police and the Border Guard are uniformed and armed formations, while the Customs Service is only a uniformed formation. This difference is not limited to terminology but also implies slightly different requirements for people applying for service in the Customs Service. However, in some cases, officers of this service may also have armaments and then, applying for service in the division in which specific tasks are performed, whose catalogue is specified in the Act on the National Revenue Administration (2016, Art. 151 section 2), candidates should meet similar requirements as in the case of the Police and Border Guard. In the case of other officers of the Customs Service, these criteria do not constitute an obstacle to establishing a service contract. The condition of no criminal record is also eased, limited only to clean criminal record for intentional crime or intentional fiscal offense.

\section{Selection of employees in uniformed services}

The candidate is admitted to the service after completing the recruitment procedure, aimed at determining whether he/she meets the conditions for admission to service. The qualifying procedure is multi-stage and time-consuming. A well-conducted selection, however, reduces the risk of a prompt quitting the service by the future officer, thereby compensating for the effort put into the recruitment process itself. Table 1 presents the stages of qualification proceedings in individual services.

In principle, the course of the recruitment procedures for each of the services are very similar. During the interview, the candidate's social attitude towards people, the ability to self-presentation, the correctness of formulating thoughts, the ability to make contact, communicate, the level of eloquence, the scope of knowledge and motivation to undertake the service are made. Psychological tests are aimed at determining the intellectual and personality predispositions of the candidate (social behaviour, stability, attitude at work). Physical and mental ability, or health status and fitness for service are 


\begin{tabular}{|c|c|c|c|c|}
\hline No. & Recruitment stages & Police & $\begin{array}{l}\text { Border } \\
\text { Guard }\end{array}$ & $\begin{array}{l}\text { Customs } \\
\text { Service }\end{array}$ \\
\hline 1. & $\begin{array}{l}\text { Application for admission to the service, personal questionnaire, } \\
\text { documents stating the required education and professional } \\
\text { qualifications and containing data on previous employment }\end{array}$ & $x$ & $x$ & $x$ \\
\hline 2. & Knowledge test & $x$ & $x$ & $x$ \\
\hline 3. & Foreign language test & & $x$ & \\
\hline 4. & Physical efficiency test & $x$ & $x$ & $x$ \\
\hline 5. & Psychological test & $x$ & $x$ & $x$ \\
\hline 6. & Competence test & & & $x$ \\
\hline 7. & Interview & $x$ & $x$ & $x$ \\
\hline 8. & Physical and psychical compliance procedure & $x$ & $x$ & $x$ \\
\hline 9. & $\begin{array}{l}\text { Checking the veracity, records and files of the data contained in the } \\
\text { candidate's personal questionnaire }\end{array}$ & $x$ & $\mathrm{x}$ & $x$ \\
\hline 10. & $\begin{array}{l}\text { Verification procedure specified in the regulations on the protection } \\
\text { of classified information }\end{array}$ & $x$ & $x$ & $x$ \\
\hline 11. & Psychophysiological tests & & $x$ & $x$ \\
\hline
\end{tabular}

Selected Aspects of Human Resource Management in Uniformed Services

Table 1.

Recruitment stages in individual formations

Source: Author's own study based on the Regulations (2012), (2006), (2018b).

determined by the medical committees subordinate to the minister competent for internal affairs. Differences in the case of candidates applying for admission to the Border Guard service limit to the need to pass a test of proficiency in a foreign language, and in the case of candidates applying for admission to the Customs Service - to the need to pass a competence test. Candidates for police service, however, do not undergo obligatory psychophysiological examination. It is also worth noting that in cases justified by the needs of the service or qualifications of the candidate for service in the Customs Service, the Head of the National Revenue Administration may release the candidate from certain stages of the recruitment procedure.

The Police Act (1990, Art. 25a), the Act on the National Revenue Administration (2016), and the Act on the Border Guard (1990, Art. 31a) provide for the possibility of transferring officers between services. Each Police officer, Border Guard and Customs Service may at his/her own request be transferred from one of these services to another, if he/she demonstrates special predispositions to perform this service or has particularly useful qualifications.

The results of research conducted by Dzieńdziora and Smolarek indicate that in the respondents' opinions, the level of point criteria, especially in the case of psychological tests, required in the selection process is excessively high. They also pointed out the necessity to diversify the fitness criteria in the physical fitness test, due to the biological conditions of candidates of both sexes. In the respondents' opinions, the selection process takes too long, which is a significant obstacle in candidates' careers. However, despite the fact that the qualification procedures require meeting high criteria, having appropriate professional predispositions and the necessary psychophysical features, in the opinion of the respondents they do not bring the effect of selecting the best candidates. The process of selection for service requires further improvement (Dzieńdziora and Smolarek, 2013). 
IJSR 7

\section{Maintenance and development of employees in selected uniformed services}

Threat to health and life is included in the work of uniformed services officers. The service assumes a multi-shift work system, which requires the officers to be available, disciplined and resistant to long-term effort. Persons admitted to this formation must meet many requirements, have appropriate psychological features and demonstrate a high level of physical fitness. During the service, officers are subject to a continuous training process, whose aim is to constantly maintain readiness to properly perform their duties in the realities of variable legal provisions. The officer must constantly take care of the physical form and develop his/her skills of shooting or combat. The psychological resistance of officers and the level of stress experienced may be influenced by the nature of the tasks performed, often dangerous to life and health. The negative effect of these factors is compounded by rising expectations as to the qualifications, flexibility and efficiency of the work of officers in a situation where they do not have a total impact on the circumstances in which they are to perform their duties. The officers must meet the expectations of superiors and team members and act in such a way that the cooperation is efficient and allows to perform their tasks optimally. In addition, the situation during the service is characterized by high dynamics of changes and requires constant readiness to make quick decisions and adequate to the situation of the reaction. Therefore, the quality of social relations in the workplace, the sense of receiving support from colleagues, establishing relationships based on cooperation, the feeling of being appreciated and rewarded are of particular importance (Chudzicka-Czupała et al., 2018).

The results of research conducted in various formations of uniformed services indicate a significant similarity of the factors motivating the officers to act (cf. Brzeźniak et al., 2012; Mazuryk and Zuzankiewicz, 2015; Szymańska, 2017; Terebińska, 2017; Chudzicka-Czupała et al., 2018).

As can be seen from the three editions of surveys carried out by Brzeźniak et al., the level of satisfaction of police officers in their work was invariably affected by stable employment, the percentage of people claiming that their satisfaction is influenced by stable employment working conditions and good relations with colleagues was at a similar level. However, it should be stated that the satisfaction of the respondents is less and less influenced by: relatively good remuneration and good relations with superiors. Analysing the factors causing dissatisfaction with work, more than half of the respondents indicated relatively low remuneration and excess paperwork, bureaucracy, $1 / 3$ of respondents indicated constant organizational changes and unfair treatment and poor working conditions, while $1 / 5$ - no promotion opportunities. It can be noticed that the dissatisfaction due to the relatively low salary and lack of promotion opportunities remained at a similar level, the excess of formalities, bureaucracy is slightly increasing, whereas the percentage of people dissatisfied with constant organizational changes, unfair treatment and poor working conditions (equipment, etc.) is gradually decreasing. Everyday work is difficult for the respondents, above all, due to excessive bureaucracy and work for statistics, for $1 / 4$ of those surveyed, the problem is too short time for performing certain tasks, and for $1 / 5$ - excessive workload. Comparable results are maintained in all editions of the study (Brzeźniak et al., 2012). 
Research carried out by Chudzicka-Czupała and others showed that the Border Guard officers who have a significantly lower sense of influence on the way the job is performed, lack of independence in this matter, fewer possibilities of making autonomous decisions, a significantly higher sense of workload, who feel that superiors provide them with the necessary tools to work to a lesser extent, are significantly more vulnerable to discomfort caused by stress at work. Similarly, there is higher dissatisfaction among officers who rarely experience appreciation from colleagues and whose effort is often unnoticed and underestimated by supervisors. Significant differences also apply to the assessment of areas of professional life related to social aspects of work, such as the lack of mutual trust, support and cooperation in the team and the dimension related to the need to break the rules and compulsion to go against their own internalized values. Those who have a worse assessment of these aspects of work experience much higher discomfort in connection with work, they are characterized by a significantly higher level of perceived stress. Important factors for the well-being of people working in this profession are a sense of control at work, related to a sense of security and support from the management (Chudzicka-Czupała et al., 2018).

A significant impact on the level of satisfaction of officers is the possibility of promotion. In uniformed formations, where, in principle, orders requiring the subordination to the superior's decision are issued, the official grades acquire a special meaning. In the case of the Police, Border Guard or Customs Service, corps and degrees are created, which creates a hierarchy of service. The location of individual positions allows not only to shape the employment policy but, more importantly, affects the prestige of the officer. The introduction of service levels means that the career of an officer is no longer limited only to occupying successive positions, but also focuses on the pursuit of the highest level of service. A workplace promotion is also a prize and distinction for exemplary performance of official duties. Getting a higher professional position means entering a higher-valued group than the one which the person is currently associated with. People care about being valued, enjoying recognition and esteem, which is why prestige is a valued good, a kind of psychological reward, and above all a dimension in the social hierarchy, the most important one apart from material status and power. Prestige is a vast sphere of assessments, often hidden or unconscious, which is sometimes not revealed (Poklek, 2015). In the case of officers, prestige is defined not only as a mix of respect, recognition and dignity but also as belonging to a specific corps and having a certain degree of service. The hierarchical structure of positions in each service becomes the determinant of the position of the individual in the organization. The vertical path of the officer's promotion means climbing the next levels of professional career, in which one level is superior to the other and in which there is a borderline, which is the overriding goal - the highest position in the hierarchy. The officer's official rank is a visible element of the uniform, allowing to determine the position of a given officer in the service.

The applicable legal provisions precisely specify the requirements for officers on particular levels and in terms of who has the right to appoint those ranks. These requirements apply to education, position held and the minimum period of service in a given rank. In particularly justified cases, it is possible to appoint officers to a higher level of service more quickly before the minimum periods of service in the current position, if the officer has special professional qualifications or specific skills to perform
Selected

Aspects

of Human

Resource

Management

in Uniformed

Services 
IJSR 7

the service, or deserves to be distinguished. The "statutory" period provided by the legislator allows:

- in the case of the Police - a minimum age for a sentinel to obtain the rank of Superintendent (first rank in the generals' corps) is 42 years;

- in the case of the Border Guard - a minimum age for a corporal to obtain the rank of Brigadier General is 38 years;

- in the case of the Customs Service - a minimum age for a senior applicant to obtain the rank of general is 28 years.

The detailed procedure for the appointment of officers to particular levels, the entities competent to submit applications, templates for the application for appointment, the required qualifications and skills and appointment periods are defined in: Regulation of the Minister of Interior and Administration of 19 July 2007 on the appointment of police officers for police ranks (2007), Regulation of the Minister of Internal Affairs and Administration of 17 August 2005 on the detailed procedure for the appointment of officers to the rank of Border Guard (2005), and Regulation of the Minister of Finance of 29 January 2018 regarding the appointment of officers in the Customs Service for a service level (2018).

\section{Conclusions}

The basic mutual element connecting the Police, the Border Guard, and the Customs Service is, of course, the uniforms and subordination of the officers. It is impossible to ignore the centralism of the organizational structure and hierarchical subordination. The activities of these services, including the implementation of the human resource management process, as set out above, are governed by relevant legal provisions. The scope of tasks, powers and responsibilities, the process of personnel selection, evaluation, promotion, but also pension provisions are strictly regulated. To a large extent, the implementation of personnel policy from the one applied in the sphere of civilian economy is distinguishing. Introduction of any change requires changing the applicable law. However, it is advisable to take measures to improve working conditions or increase the independence of officers in the areas where it is possible, for example, by enabling and encouraging employees to participate in some decisions or delegating certain tasks to independent, responsible employees in order to increase their sense of autonomy and independence. Officers' satisfaction with the received rewards should also be increased by using reinforcements, such as, for example, appreciation of achievements, especially by superiors. It is also advisable to reduce the degree of workload, mainly tasks which are too difficult for individual people, exceeding their capabilities. It is connected with the necessity of conducting appropriate trainings, increasing employment, improving the working conditions, which all together requires increasing budgetary expenditures on uniformed services.

All these services are an essential link in the organizational structure of the state, affecting directly the maintenance of social order and the legal order. First of all, officers are obliged to take the oath, have no right to strike, they cannot belong to political parties or are obliged to make property declarations. Regardless of criminal liability, all officers also bear disciplinary responsibility. 
Due to the scope of tasks for each of these formations precisely defined by the legislator, in spite of many convergent aspects related to the status of an officer, under no circumstances should there be equality between police officers, Border Guard or the Customs Service. One can, however, recognize the mutual autonomy of these formations, make comparisons of selected areas, which was expressed in this article.

\section{References}

Adamiec, M., and Kożusznik, B. (2000), Zarządzanie zasobami ludzkimi, Wydawnictwo AKADE, Kraków.

Armstrong, M. (2007), Zarządzanie zasobami ludzkimi, Oficyna a Wolters Kluwer Business, Kraków. Brzeźniak, A., Chmielewska, A., and Lesiak, M. (2012), Satysfakcja z pracy policjantów i pracowników Policji. Raport z badań, Wydział Analiz Gabinetu KGP, Warszawa.

Chudzicka-Czupała, A., Stasiła-Sieradzka, M., Dobrowolska, M., and Kułakowska, A. (2018), "Ocena obszarów życia zawodowego funkcjonariuszy Straży Granicznej a nasilenie stresu", Medycyna Pracy, vol. 69, no. 2, pp. 199-210.

De Cenzo, D.A., and Robbins, S.P. (2002), Podstawy zarzadzania, PWE, Warszawa.

Dubisz, S. (red.) (2008a), Uniwersalny stownik języka polskiego, vol. 2, Wydawnictwo Naukowe PWN, Warszawa.

Dubisz, S. (red.) (2008b), Uniwersalny stownik języka polskiego, vol. 3, Wydawnictwo Naukowe PWN, Warszawa.

Dzieńdziora, J., and Smolarek, M. (2013), „Wybrane aspekty doboru personelu w administracji publicznej”, Zeszyty Naukowe Wyższej Szkoły Humanitas w Sosnowcu. Zarządzanie, pp. 36-47.

Frączkiewicz-Wronka, A. (red.) (2009), Zarzadzanie publiczne - elementy teorii i praktyki, Wydawnictwo Uniwersytetu Ekonomicznego w Katowicach. Katowice.

Gawroński, H. (2014), Zarządzanie publiczne w polskich samorządach terytorialnych, Wydawnictwo Państwowej Wyższej Szkoły Zawodowej w Elblągu, Elbląg.

Homeberg, F., McCarthy, D., and Tabvuama, V. (2015), "A meta-analysis of the relationship between public service motivation and job satisfaction", Public Administration Review, vol. 75, no. 5, pp. 711-722.

Jabłońska-Wołoszyn, M., and Piotrowska-Trybull, M. (2018), „Wybrane aspekty potencjału kobiet w Siłach Zbrojnych RP”, in: E. Waśko-Owsiejczuk (red.), Kobiety w polskich stużbach mundurowych - role, zadania i wyzwania, Oficyna Wydawnicza ASPRA, Warszawa, pp. $157-172$.

Kuczyński T. (2011), „Stosunki służbowe służb zmilitaryzowanych (mundurowych)”, in: T. Kuczyński, E. Mazurek-Jasińska, J. Stelina (red.), System prawa administracyjnego, C.H. Beck, Warszawa, pp. 14-22.

Lane, J.E. (2000), The Public Sector. Concepts. Models and Approaches, Sage Publications, London.

Laszuk, M. (2013), „Współpraca administracji celnej z organami administracji państwowej, samorządowej oraz samorządem gospodarczym”, in: B. Polszakiewicz, J. Boehlke (red.), Ekonomia i Prawo, vol. XII, Wydawnictwo Uniwersytetu Mikołaja Kopernika, Toruń, pp. $127-138$.

Liwo, M. (2015), „Służby mundurowe jako kategoria języka prawniczego”, Przegląd Prawa Publicznego, no. 2, pp. 9-22.

Maciejewski, J. (2014), Grupy dyspozycyjne. Analiza socjologiczna, Wydawnictwo Uniwersytetu Wrocławskiego, Wrocław.

Maciejko, W., Rojewski, M., and Suławko-Karetko, A. (2011), Prawo administracyjne. Zarys wykładu części szczególnej, C.H. Beck, Warszawa.

Mazuryk, M., and Zuzankiewicz, P. (2015), „Zarządzanie zasobami ludzkimi w sektorze publicznym”, Zeszyty Naukowe. Warszawskie Seminarium Aksjologii Administracji, vol. IV, pp. 157-178.
Selected

Aspects

of Human

Resource

Management

in Uniformed

Services 
IJSR 7

Morawski, Z. (2005), Prawne determinanty pozycji, roli i statusu warstw dyspozycyjnych spoleczeństwa Polski na przyktadzie trzech organizacji formalnych, Wydawnictwo Uniwersytetu Wrocławskiego, Wrocław.

Noblet, A.J., and Rodwell, J.J. (2009), „Identifying the Predictors of Employee Health and Satisfaction in an Npm Environment", Public Management Review, vol. 11, no. 5, pp. 663-683.

Pieprzny, S. (2008), Administracja bezpieczeństwa i porzadku publicznego, Wydawnictwo Uniwersytetu Rzeszowskiego, Rzeszów.

Pike, S., Roos, G., and Marr, B. (2005), "Strategic management of intangible assets and value drivers in R\&D organizations", $R \& D$ Management, vol. 35, no. 2, pp. 111-124.

Poklek, R. (2015), Motywacja osiagnięć funkcjonariuszy Stużby Więziennej, Centralny Ośrodek Szkolenia Służby Więziennej, Kalisz.

Pollitt, Ch., and Dan, S. (2011), "The impacts of the new public management in Europe: A metaanalysis", COCOPS Work Package 1 -Deliverable 1.1, Coordinating for Cohesion in the Public Sector of the Future, p. 68.

Rozporządzenie Ministra Spraw Wewnętrznych i Administracji z dnia 17 sierpnia 2005 r. w sprawie szczegółowego trybu mianowania funkcjonariuszy na stopnie Straży Granicznej, Dz.U. 2005, nr 159, poz. 1340 ze zm. (Regulation of the Minister of Internal Affairs and Administration of 17 August 2005 on the detailed procedure for the appointment of officers to the rank of Border Guard, Journal of Laws 2005, No. 159, item 1340 as amended).

Rozporządzenie Ministra Spraw Wewnętrznych i Administracji z dnia 10 lutego 2006 r. w sprawie przeprowadzania postępowania kwalifikacyjnego w stosunku do kandydatów ubiegających się o przyjęcie do służby w Straży Granicznej, Dz.U. 2006, nr 23, poz. 175 ze zm. (Regulation of the Minister of Internal Affairs and Administration of 10 February 2006 on the recruitment procedure for candidates for service in the Border Guard, Journal of Laws 2006, No. 23, item 175 as amended).

Rozporządzenie Ministra Spraw Wewnętrznych i Administracji z dnia 19 lipca 2007 r. w sprawie mianowania policjantów na stopnie policyjne, Dz.U. 2007, nr 145, poz. 1017 ze zm. (Regulation of the Minister of Interior and Administration of 19 July 2007 on the appointment of police officers for police ranks, Journal of Laws 2007, No 145, item 1017 as amended).

Rozporządzenie Ministra Spraw Wewnętrznych z dnia 18 kwietnia 2012 r. w sprawie postępowania kwalifikacyjnego w stosunku do kandydatów ubiegających się o przyjęcie do służby w Policji, Dz.U. 2012, poz. $432 \mathrm{ze} \mathrm{zm.} \mathrm{(Regulation} \mathrm{of} \mathrm{the} \mathrm{Minister} \mathrm{of} \mathrm{Internal} \mathrm{Affairs} \mathrm{and} \mathrm{Administration}$ of 18 April 2012 on the recruitment procedure for candidates for service in the Police, Journal of Laws 2012, item 432 as amended).

Rozporządzenie Ministra Finansów z dnia 29 stycznia 2018 r. w sprawie mianowania funkcjonariusza Służby Celno-Skarbowej na stopień służbowy, Dz.U. 2018a, poz. 356 (Regulation of the Minister of Finance of 29 January 2018 regarding the appointment of officers in the Customs Service for a service level, Journal of Laws 2018a, item 356)

Rozporządzenie Ministra Finansów z dnia 23 lutego 2018 r. w sprawie informacji o wolnych stanowiskach służbowych w Służbie Celno-Skarbowej oraz postępowania kwalifikacyjnego do Służby Celno-Skarbowej, Dz.U. 2018b, poz. 449 (Regulation of the Minister of Finance of 23 February 2018 on information on vacant posts in the Customs Service and recruitment procedure for service in Customs Service, Journal of Laws 2018b, item 449).

Sayce, S. (2016), "Public service motivation for executives pension trustees: A qualitative study", International Public Management Review, vol. 17, no. 1, pp. 21-39.

Sławik, K. (2011), Zarys systemu prawa policyjnego, Wolters Kluwer, Warszawa.

Szustakiewicz, P. (2015), „Istota stosunku służbowego”, in: P. Szustakiewicz, M. Maciejko (red.), Stosunek stużbowy w formacjach mundurowych, C.H. Beck, Warszawa, pp. 1-10.

Szymańska, E. (2017), „Teoretyczne aspekty motywowania funkcjonariuszy Policji”, Obronność. Zeszyty Naukowe, vol. 4, no. 24, pp. 177-191. 
Terebińska, M. (2017), „Motywowanie pozytywne policjantów oraz pracowników policji”, Marketing i Rynek, no. 4 (CD), pp. 381-390.

Ustawa z dnia 6 kwietnia 1990 r. o Policji, Dz.U. 1990, nr 30, poz. 179 (Act on the Police of 6 April 1990, Journal of Laws 1990, No. 30, item 179).

Ustawa z dnia 12 października 1990 r. o Straży Granicznej, Dz.U. 1990, nr 78, poz. 462 (Act on the Border Guard of 12 October 1990, Journal of Laws 1990, No. 78, item 462).

Ustawa z dnia 16 listopada 2016 r. o Krajowej Administracji Skarbowej, Dz.U. 2016, poz. 1947 (Act on the National Revenue Administration of 16 November 2016, Journal of Laws 2016, item 1947).

Zawicki, M. (2011), Nowe zarzadzanie publiczne, Polskie Wydawnictwo Ekonomiczne, Warszawa.
Selected

Aspects of Human

Resource Management in Uniformed Services 